Monika Kavalir

University of Ljubljana

Slovenia
2015, Vol. 12 (1), 29-47(144)

revije.ff.uni-lj.si/elope

doi: 10.4312/elope.12.1.29-47

UDC: $81: 316.7(41: 73: 497.4)$

\title{
House and Home across Cultures
}

\begin{abstract}
Based on the assumption that language and culture are inextricably linked, the paper looks at some characteristics of the domain that can be labelled 'house and home' in the British Isles and North America, and contrasts it in particular with the situation in Slovenia(n). It examines the construction materials used, the size of people's dwellings, the use of light, colour and style, hygiene, class distinctions, and the attitude to house vs. home, showing that like almost any concept in any language, the notions of house and home are culturally determined experiences of time and spacethey are not coincidental but have to do with structural traits of the three cultures. In addition, a corpus analysis of expressions to do with house and home is carried out to demonstrate the intimate link between language and culture and to show that mastery of a language goes hand in hand with understanding the target society/societies.
\end{abstract}

Keywords: language and culture; British culture; American culture; Slovenian culture; collocations

\section{Hiša in dom $v$ različnih kulturah}

\section{POVZETEK}

Članek temelji na predpostavki, da sta jezik in kultura neločljivo povezana, in na tej osnovi obravnava nekatere značilnosti domene, ki jo lahko poimenujemo "hiša in dom«, na Britanskem otočju in v Severni Ameriki ter jo primerja s slovensko situacijo. Ob podrobnejšem pregledu gradbenih materialov, velikosti stanovanj, rabe svetlobe, barv in slogov, higiene, razlikovanja med družbenimi razredi in odnosa do hiše v primerjavi z domom je pokazano, da sta, kot skoraj vsak koncept v vsakem jeziku, pojma hiše in doma kulturno določeni izkušnji časa in prostora - tu ne gre za naključje, temveč za povezavo s strukturnimi značilnostmi obravnavanih kultur. Razpravo dopolnjuje korpusna analiza izrazov, povezanih s hišo oziroma domom, ki jasno pokaže tesno povezavo med jezikom in kulturo ter ponazori, kako pomembno je razumevanje ciljne kulture oziroma kultur za obvladovanje jezika.

Ključne besede: jezik in kultura; britanska kultura; ameriška kultura; slovenska kultura; kolokacije 


\section{House and Home across Cultures}

\section{Introduction}

When it comes to the sphere of house and home, the differences between cultures are noticeable enough for migrants of any kind - travellers, expatriates, and others - to marvel at. It is easy to look in consternation at the cylindrical pillow on your bed in France, or to wonder why it is your Slovenian hosts want to force slippers on you as you enter their home. These same differences may not be quite so accessible to students of a particular language and culture abroad, however, as they are not physically confronted with them. Furthermore, even when outsiders are aware of the intricacies of domestic life in a particular corner of the world, understanding where they stem from and how they fit into the context of that culture may be beyond their grasp.

Taking as granted that language and culture are closely linked, the paper examines some characteristics of the domain that can be labelled 'house and home' in the British Isles and in North America, and contrasts them in particular with the Slovenian language-and-culture (in terms of Byram, Morgan et al. 1994). Like almost any concept in any language, these notions are culturally determined experiences of time and space. Thus, to be able to study them in another culture, one must necessarily become aware of one's own cultural concepts in the field. A major part of this undertaking therefore revolves around conceptualising differences between the individual's own culture and the target culture.

The purpose of the paper is two-fold. First, it examines the domain of house and home to show that there are considerable differences between the three cultural milieux, and that these differences are not coincidental but have to do with structural traits of the three cultures. Second, it uses a corpus analysis of the expressions involved to demonstrate the link between language and culture in this specific area and to show that mastery of a language goes hand in hand with understanding the target society/societies.

\section{Culture and Its Relationship to Language}

For the purposes of this article, culture is understood as "a fuzzy set of basic assumptions and values, orientations to life, beliefs, policies, procedures and behavioural conventions that are shared by a group of people, and that influence (but do not determine) each member's behaviour and his/her interpretations of the 'meaning' of other people's behaviour" (Spencer-Oatey 2008, 3). The groups in question correspond to the American, British, and Slovenian societies. ${ }^{1}$

It is easy enough to start listing specific traits of an individual society that make it stand apart when compared with other cultures, but it takes a greater effort to see how they are interrelated and how they connect in a dynamic system that is the "'grammar' - or 'mindset' or 'ethos' or 'gemeingeist' or 'cultural genome' or whatever you want to call it" (Fox 2001, 400) of that culture. Offering such an overview is well beyond the scope of this paper and yet it sheds light on the place that house and home take in the cultural network of a particular society - somewhat in the spirit of cultural relativism, which sees a culture as a "social world that reproduces itself through enculturation" and naturally engenders ethnocentrism, that is the belief that one's values and practices are "uniquely satisfying and superior to all others" (Brown 2008, 364-65).

Where applicable, reference is made to individual 'subcultures' (for instance, the Scottish culture); most of what is described here as 'British' is prototypically English (cf. Fox 2001, 21) but applies throughout the British Isles. 
Importantly, the approach taken here should not be understood as essentialist or nationist, as it does not assume a straightforward member/non-member interpretation of a collective identity for all citizens of a country or region. Instead, the way the British/American/Slovenian culture is described should be seen as an abstract social group with considerable dynamism in its membership and in a creative relationship with a number of other cultural identities. An individual living in one of these societies can thus exhibit the characteristics described fully, partly, or not at all, but this does not mean that they do not hold true for the society as a whole.

How are language and culture related? While there have been claims that there is a strong dichotomy between language and culture, and the latter has at times been seen as "contents conveyed by language, but separate from language" (as discussed in Penz 2001, 103), nowadays the great majority of scholars (for instance, in Senft, Östman, and Verschueren 2009; Trosborg 2010; Hager 2011; Son and Dashwood 2011), and indeed the public at large, agree that language and culture are intimately linked. The relationship seems to be very complex, however, and there have been different views on the directionality of the relationship.

There are many examples of language being used differently across societies and subcultures within societies, and the different pragmatics give rise to different language systems (for instance, in terms of honorifics, kinship vocabulary, etc.) or sublanguages (for instance, with marked differences according to register). The Sapir-Whorf hypothesis, on the other hand, is traditionally taken to claim also that language influences thought, and thus culture. The present study makes no such claims, but it does relate to the weak version of the hypothesis, acknowledging that "there are cultural differences in the semantic associations evoked by seemingly common concepts" (Kramsch [1998] 2014, 13).

Crossing boundaries from one language to another, culture will inevitably enter the fray, and there is fruitful interaction taking place between cultural awareness and language awareness, which are "both seen as essential aspects of communicative competence and inseparable from it" (Fenner 2001, 7). This acknowledgement has become particularly important in the field of language learning and teaching: "Since language and culture are inseparable, we cannot be teachers of language without being teachers of culture - or vice versa" (Byram, Morgan et al. 1994, vii). ${ }^{2}$

Building on prototype theory (Rosch 1978), one could say that in their lexicon, a Briton, a U.S. American and a Slovenian have specific prototypical mental representations of what a house or a home is, and that these concepts overlap to a certain extent. There is often enough of a match for them to think they are referring to exactly the same notions when some important details might be different. These differences can be a source of misunderstandings - particularly because speakers communicate under the assumption that 'they are talking about the same thing'.

To test the hypothesis about the relatedness of language and culture in this domain, the notions of 'house' and 'home' (bisa and dom in Slovenian, respectively) are investigated with the help of a corpus analysis where appropriate (not all topics lend themselves to a corpus investigation, however). For British English, the British National Corpus (BNC - 100 million words covering the period between 1960 and 1993; Burnard 2007) is used utilising the BNCweb platform; searches for American English are done using the online Corpus of Contemporary American English (COCA - 450 million words covering the period between 1990 and 2012; information

While it is recognized that learner identities are fluent, the paper does not touch upon identity changes occurring when acquiring a new language, or on affective factors influencing the process, such as "social distance" and "psychological distance" (Schumann 1976 in Holliday, Hyde, and Kullman [2004] 2006, 80-81). 
given as part of the corpus interface); and the online corpus Gigafida (600 million words covering the period between 1990 and 2011; Amebis, n.d.) is used for Slovenian. ${ }^{3}$ If possible, standard two-tailed statistical tests based on $Z$ scores are carried out $(\alpha=0.01)$; because these play only a supporting role in the discussion, technical details are kept to a minimum.

\section{What's in a House?}

Houses are not mere assemblages of bricks, roofs, rooms, doors and furniture; rather, the notion is bound to a particular time and place - and in fact every aspect mentioned can be questioned when looking at cultures across the world. Shakespeare's Juliet claims that "that which we call a rose by any other name would smell as sweet"; here, it is partly the name and the function that unites houses and homes across the world, rather than their structure. This can be seen in a number of examples, ranging from the foundations to the decorations, that are supported here with qualitative and quantitative data. ${ }^{4}$

\subsection{Masonry Construction vs. Timber-Framed Construction}

Whether or not a house is made with bricks depends on the individual builder, of course, but different parts of the world have very different inclinations. In the United States, the predominant method in constructing a house is timber-framed construction, where structural timber is used for the load-bearing part of the walls (American Forest and Paper Association 2001, 3). In the United Kingdom, masonry construction, also known as brick and block construction, has been the method traditionally used, but timber-framed construction is currently the fastest growing construction method and its share is approximately a quarter of the market (Brinkley 2009; Structural Timber Association 2014-2015), despite frequent concerns regarding fire safety (for instance, Dunton 2014). There is considerable variation present also within the United Kingdom as in some regions stone houses may still be common and Scottish homes specifically have traditionally been built with timber - in fact about two thirds of all new homes constructed in Scotland are timber-framed (UK Timber Frame Association 2010, 2).

In Slovenia, masonry construction has traditionally been the norm and civil engineering students and professionals ${ }^{5}$ tend to sneer at American claims that timber-framed construction enables "[their] nation to have the world's best housed population" (American Forest and Paper Association 2001, 3 ), or that brick is a material of the past - with some U.S. educational materials only giving wood as an appropriate material to build a house with (for instance, in WGBH Educational Foundation 2000-2001). Nevertheless, the Slovenian public is becoming more open to the idea and woodproduct based construction now has a $10 \%$ market share ("Intervju: Zdi se mi potratno, da bi si zgradil hišo iz opeke in betona" 2014), with the proportion of people aged 25-40 expressing a preference for timber-framed construction over masonry construction reportedly rising from 34\% in 2006 to 42\% in 2011 (Kitek Kuzman, Kušar, and Hrovatin 2007, 35; Kitek Kuzman and Vratuša 2011, 32). This shows that changes in perception are possible. Similarly, the growing demand for timber-framed construction in the UK is proving false such assertions as the one about masonry construction being "ingrained in [the British] national psyche" (The SelfBuild Guide 2009-2013).

All queries involve lemmas rather than words.

Due to differences in the methodologies used by different organizations, numerical data are not necessarily directly comparable and should be taken as indicative of trends rather than reflecting exact statistical differences.

5 Based on the author's experience teaching at the Faculty of Civil and Geodetic Engineering, University of Ljubljana. 
Based on the predominant trait in the culture they come from, individuals as a rule find it easier to see the advantages of what they are familiar with. This may be understandable but is also a good example of how what is known and common within a culture becomes the norm and acquires inherent superior moral value. Clearly, both methods of construction have their advantages and disadvantages according to the particular situation and locale (including the greater cost of masonry construction, differences in availability of wood, etc.), but it is easy for people - even construction professionals - to fall into the trap of assuming that what they are used to is necessarily better. Furthermore, even such details as the material used for construction may be tied to broader cultural practices - Šabec and Limon (2001, 91), for instance, link the prevalence of timberframed construction in the USA to the idea of "temporariness" and a greater mobility present in that country compared to Europe. ${ }^{6}$

The disparity between these cultural practices is to some extent reflected in the language as well. In timber-framed houses the wood is hidden inside the walls and we should not therefore expect Americans to talk significantly more about 'wooden houses'. When we turn our attention to masonry construction, however, the situation is noticeably different. In the vicinity (defined as a window span of five places to the left or right) of hisa (house), the Slovenian corpus Gigafida returns 276 instances of opeka (brick, n.), 132 instances of opečnat (brick, adj.), and 689 instances of zidan (built with brick or stone). In the American corpus COCA, on the other hand, there are 573 hits for 'brick' in relation to 'house' and 8 hits for 'masonry'. Even after adjusting for the different sizes of the corpora, the difference is statistically significant. ${ }^{7}$

\subsection{Size}

In both the UK and Slovenia, the average usable floor area of a household is approximately $100 \mathrm{~m}^{2}$ for a house and a little less than $60 \mathrm{~m}^{2}$ for a flat, but there is a considerable difference in the average household size, with $92 \mathrm{~m}^{2}$ in the UK vs. $80 \mathrm{~m}^{2}$ in Slovenia (Department for Communities and Local Government 2014, 67-68; Dolenc et al. 2013, 42-44). The difference is due to the fact that flats are a much more common type of housing in Slovenia compared to the UK: in Britain, $81 \%$ of all dwellings are houses or bungalows, whereas detached and semi-detached houses account for only 61\% of Slovenian households (Department for Communities and Local Government 2010, 8; Dolenc et al. 2013, 42).

On the whole, the British attitude to flats is strongly negative (see for instance, Šabec and Limon 2001, 103), and O'Driscoll $(2004,174-75)$ finds this puzzling:

The people who live in [flats] are those who cannot afford to live anywhere else [...] In theory (and except for the difficulty with supervising children), there is no objective reason why these high-rise blocks (also known as 'tower blocks') could not have been a success. In other countries millions of people live reasonably happy in flats. But in Britain they were a failure because they do not suit British attitudes.

The reason he hints at, lack of privacy, would indeed seem to be relevant. Fox (2004) cites respect for privacy as one of the most important determiners of British culture. One particular trait that

The issue of material used serves only as a basic example of structural differences present and many more could be explored, for instance, types of windows (sash, bay, etc.), use of transition spaces (porch, patio, etc.), as well as different attitudes to the same elements (for instance, double glazing).

Using the same parameters, a further comparison with the British corpus BNC yields unexpected results with as few as 51 instances of 'brick' and only 3 instances of 'masonry' in the vicinity of 'house'. While this corpus is much smaller compared to the other two, the adjusted figures are still so low as to suggest there might be a difference at play in the make-up of the corpora. 
she notices can be linked to the field of house and home: the moat-and-drawbridge rule, whereby street names and house numbers are "camouflaged" indicating "an obsession with privacy" (Fox 2004, 111-13).

Compared to Europe, the USA seems to be characterized by much greater variation and extremes in terms of size, with homes ranging from sprawling mansions to trailers in trailer parks. The median size of occupied housing units in a 2011 survey was found to be approximately $167 \mathrm{~m}^{2}$, or 1,800 square feet (U.S. Department of Housing and Urban Development / U.S. Census Bureau 2013, 10), confirming the impression that American homes tend to be much larger than European ones. ${ }^{8}$ The share of single-family detached or attached houses (including, for instance, terraced houses) is between 65 and 70\% and has not seen major fluctuation since 1940 (U.S. Census Bureau, Housing and Household Economic Statistics Division 2011), which shows that not only houses but also flats are more spacious. While considerable differences can be observed within the country - the data can be severely skewed in metropolitan areas such as New York due to population density and high real estate prices - this is true of all three countries under analysis.

Besides other contributing factors, such as the early history of European settlers in the United States when land was seen as available to anyone, one aspect that can help explain these differences is in-country mobility and the notion of the 'guest bedroom. ' ${ }^{9}$ Where the size of the country enables or encourages regular contact between family members, school friends, etc., visits continuing over several days will typically be less frequent, and extra rooms to accommodate the visitors will not be needed to the same extent. This difference is reflected both in the OECD data, which show that on average, U.S. Americans have 2.3 rooms per person while the British have 1.9 and Slovenians 1.4 rooms per person (OECD, n.d.), and in cultural attitudes, where to a Slovenian the idea of a guest bedroom typically just means wasted space.

A similar impression can be expected when people coming from cultures such as Slovenian, where "waste not, want not" is the motto (see Blake 2011, 100), are faced with the fact that American homes tend to have more bathrooms than European ones. Apparently, the American ideal is for each bedroom to have its own bathroom (see, for instance, Richmond 2009, 39): extra bathrooms can be seen as a status symbol and houses with a single bathroom are difficult to sell (see Schmich 2011). Perhaps surprisingly, given the British stress on privacy, homes in the UK do not normally have more than a single bathroom, with approximately $40 \%$ of dwellings having a second toilet and only $21 \%$ having a second shower or bathroom, compared to $63 \%$ and $51 \%$, respectively, in the USA (Department for Communities and Local Government 2010, 30; U.S. Department of Housing and Urban Development / U.S. Census Bureau 2013, 5). It is equally telling that the Statistical Office of the Republic of Slovenia does not collect information about the number of bathrooms per household unit (only whether there is at least one bathroom on the premises).

The concept of house size is another one where the normative nature of lived everyday experience is easy to observe. When asked to compare the size of Slovenian homes to American ones, students taking English courses at the Faculty of Civil Engineering, University of Ljubljana, tend to describe Slovenian houses as "average" - a notion that in this case makes more sense in comparisons within than across countries - or "just right", and members of a particular culture will tend to rationalize their preferences by producing a variety of arguments such as cosiness, intimacy, effort taken to

There is considerable variation across the continent, of course. Deane $(2014,53)$, for instance, reports that German houses "are far bigger than British houses with large gardens front and back, a cellar, an attic, a utility room, guest room and plenty of space.”

9 Richmond (2009, 37-39) links big houses to individualism as an important characteristic of Americans and sees them as just one more example of the "American fascination with size," on a par with supersize hamburgers and the popularity of SUVs. 
clean the home, etc. In this way, what is common in one's culture is redeemed against other, different practices, which can justifiably be looked down upon.

What this means for language use is that when Slovenian, British, or American speakers talk about 'a big/small house' (or velika/majhna hiša), they may feel they are talking about the same thing but in reality, what a Slovenian (or Briton) considers a big house may still be small to an American. This is a classic example of important cross-cultural semantic differences between what are seemingly the same expressions.

\subsection{Light, Colour and Style}

The paper makes no pretensions towards describing all the many differences present in terms of interior design, especially since differences between individual tastes tend to be much more pronounced than those between any national cultures. Nevertheless it can be argued that some perceptions of particular traits are characterized by a mainstream cultural element. Using the notions of creative and inherited cultural identities (see Holliday, Hyde, and Kullman [2004] 2006, 18-19), furniture and decoration styles are typically part of one's creative identity but some details are inherited even if individuals are not aware of this.

One such notion is that of light and the preference for better or less well-lit spaces. While styles change from person to person and historical period to historical period, the United Kingdom tends to have a greater tolerance for sombreness with respect to light and colours compared to either Slovenia or the USA. Quite apart from any weather-related phenomena, two particular contributing factors will be presented here, the so-called Window Tax and the influence of the Bauhaus Movement in Germany - although many other influences have doubtlessly had a hand in shaping today's preferences.

First of all, something that is alien to the other two countries is the Window Tax that was introduced in the UK in the 1690s, giving birth to the expression 'daylight robbery', and was in effect during the 18th and 19th centuries. The variable part of the tax depended on the number of windows installed, and as a result it became common practice to brick up window-spaces (Martin 1996-2015; "Window Tax" 2002). It is not too difficult to imagine that later generations born into such less than well-lit environments would consider them the usual state of affairs, which is all it takes for the process of transforming what is normal into what is the norm to start - and even today examples can occasionally be seen of new buildings being constructed with faux bricked-up windows (see Martin 1996-2015).

Another easily observable difference is in the choice of colours for interior house walls and the (un)popularity of wallpaper. The prevalence of white as the colour of choice, rejection of ornamental wall coverings and a particular focus on light in both the American and Slovenian societies can be traced back to Walter Gropius and the work of the Bauhaus School that grew out of Weimar in Germany in the 1920s and early 1930s. Part of the modernist movement, the artists involved paid particular attention to the notion of usefulness and found beauty in function. Their influence spread quickly around Central Europe, including the Slovenian territory, and later on to the USA when, persecuted by the Nazi regime on the eve of World War II (see "Bauhaus" 2013), they scattered around the world. Importantly, their ideas never had the same kind of impact in countries like Britain or France: to a British person these styles may therefore seem cold, bare and impersonal, whereas the functionally-minded Slovenian or American might find the interiors in the UK dark and oppressively stuffy. 
While this particular area does not yield itself very well to corpus investigations, it can be informative to take a look at how frequently the lemma 'wallpaper', or tapeta (usually in the plural, tapete) appears in the chosen American, British, and Slovenian corpora. The raw frequencies are 1,782 hits in COCA, 472 hits in the BNC, and 4,224 hits in Gigafida. Two adjustments are in order. First, it makes sense to exclude all instances of the Slovenian metaphorical expression na tapeti (on the wallpaper), meaning 'under attack, discussion, consideration, etc.' and accounting for as many as 1,424 hits. Normalized, the figures correspond to 3.96 hits per million words in COCA, 4.72 hits in the BNC, and 4.67 in Gigafida.

The difference between the American and British corpora is expected and corroborates the ideas discussed; the observed discrepancies are statistically significant. Expectations are not met when the Slovenian data are taken into consideration, however, as the number of instances in Gigafida is much closer to the British than the American corpus. This irregularity can be explained as a result of the different semantic scope of tapeta compared to 'wallpaper': in Slovenian, tapeta is not only used for walls but can refer to different kinds of upholstery, for instance, on doors or in a car. In addition, corpus examples also testify to the fact that tapeta can (or could in the earlier days of computer software being translated into Slovenian) mean 'wallpaper' in the sense of a computer desktop background, a use that is presumably recorded much more in Gigafida compared to the BNC simply because the former corpus is newer - and there are of course precious few differences in what computers look like in different countries. ${ }^{10}$ Of course, there are some differences that corpus results do not reveal, for instance, that wallpaper in Slovenia, when used, tends to be of the non-patterned beige variety.

\subsection{Hygiene}

Anecdotal evidence piles up to suggest that hygiene in general may not be a particular concern for Britons, with international students complaining about and trying to avoid sharing a kitchen with the locals, and the requisite spider being part of the stereotypical image of the British bathroom (for instance, in The How to Be British Collection, Ford and Legon 2003). This is not to say that people born in Britain are inherently less hygienic than those growing up elsewhere; across the globe, individuals can be found at either end of the cleanliness continuum. However, what can be pointed out is that some traits and behaviours may be treated as more or less acceptable by the local culture. The roots of these cultural beliefs might have to do with objective circumstances (for instance, the presence of mould due to high humidity in the UK) but others can be shown to be associated with events that have shaped the national culture.

A case in point is the abysmal state of common kitchens in British student residences, compared to the much cleaner spaces in Slovenian halls of residence. ${ }^{11}$ Article 49 of the Dormitory Rules of Študentski Dom [Student Residences] Ljubljana (Council of Študentski Dom Ljubljana 2014) states, among other, the following:

The residents are themselves and together responsible for cleanliness and hygiene in rooms, apartments and common areas. Residents must change their bed linen at least once every two weeks, in accordance with the schedule published by the keeper. In case of absence the residents must ensure that their co-residents change their bed linen for them [...] Internal

10 Surprisingly, this use of 'wallpaper' is almost non-existent in COCA, even though this corpus is based on texts originating in the period 1990-2012.

11 The claims about the Slovenian situation in this section are based on participant observation and an informal survey; significant variation is possible between different years and residences. 
cleanliness control is carried out based on the Rules on the work of the hygiene committee which is an integral part of these Dormitory Rules. Competent authorities carry out preventive health checks of the premises.

Similar stipulations exist across countries but there are important differences in how (if at all) they are enforced. In Slovenia, control over the state of the premises is exercised by the hygiene committee through the feared 'inspections' taking place several times a year (on pre-announced dates), and hygiene must be immaculate under threat of eviction. What is more, despite the stress and effort involved, the residents typically favour this arrangement and feel such interventions are justified. ${ }^{12}$ Although they may not exercise their rights as a matter of course, the authorities can also request the residents to undergo health checks (Article 51) and fulfil various other duties related to public health.

Such an approach is unthinkable in British halls of residence. ${ }^{13}$ The difference in how the residents' privacy is perceived can be linked to the differences in the social systems the two countries have experienced. On a political and social level, the British protection of privacy is related to the idea of personal freedom and the authorities should not infringe on it unless this is indisputably warranted.

The experience of having lived under a socialist regime (1945-1991), where the state was allpowerful and in many cases could significantly direct a person's life, means that still today the Slovenian populace is more tolerant of interference by the authorities in their daily life - and in fact often expects and welcomes it, rather than transferring the burden of responsibility onto the shoulders of the individual. ${ }^{14}$

It is true that the right to privacy is recognized by all signatory countries to the European Convention on Human Rights (Art. 8; Council of Europe 1950), but it is limited in the sense that interference is allowed in line with the principles of necessity and proportionality. In the UK, where "[t]he concept of private life $[\ldots]$ is based on the classic civil liberties notion that the state should not intrude into the private sphere without strict justification" (Equality and Human Rights Commission 2012, 260), the long-standing tradition means the standards for what is deemed necessary and proportionate will often be stricter than in countries where privacy protection has historically enjoyed less privilege.

\subsection{Class Distinctions}

Fox (2004, 115-19) has a comprehensive list of decorative traits that mark various social classes in England. Upper and upper-middle-class homes are "shabby, frayed and unkempt" with "old, threadbare and mismatched furniture" (the same is true of lower-working classes and below, but for the former the reason is that these are antique pieces that have been inherited, for the latter it is simply the lack of money to renovate), "bare floorboards, often part-covered with old Persian carpets or rugs", a separate TV room, plain white bathrooms, and a "brag wall" (a display of photographs and awards) in the loo. The dwellings of working-class nouveaux riches are furnished with extremely expensive items, for instance, leather sofas. Both the middle-middle class and the classes below favour fitted carpets and a prominent brag wall, while cocktail cabinets, hostess trolleys and brand new

12 In fact, the feeling is shared by one of the reviewers of this article.

13 To a large extent, the issue is moot in the United States because most students who stay in residences opt for a meal plan and do not cook (consequently, there are often no cooking facilities available).

14 Budak, Anić, and Rajh $(2013,102)$ similarly talk about "the public mindset inherited from the past regime" with regard to cases of low awareness about privacy protection legislation in Croatia, which was likewise part of former Yugoslavia. 
matching furniture are specific to the middle-middle class. Lower-middle and working-class homes can be recognized by net curtains, embroidered armchair covers and collections of small objects or, as an alternative, by a waiting-room-like décor, but in any case they will contain large TV sets and colourful bathrooms, and these are also the homes where drink coasters are used.

Although no such in-depth studies are available for the USA and Slovenia, on its own this does not mean such class differences are not present. Compared to the UK, it can be argued that in the U.S. the disparities are just as great or perhaps greater. They are not, however, shown so much in the way homes are decorated (due to the size of the country, this may have more to do with the weather and regional influences) but in the sheer size of the property and the number of rooms (and of course bathrooms) that one can afford.

One particular example that stands out in the American culture is the relatively large number of people permanently inhabiting mobile homes and trailers. In the British Isles and Slovenia this is not unknown; however, it is associated with only a tiny sliver of the population, mainly particular ethnic communities (for instance, Travellers - traditionally itinerant ethnic groups - in Britain and Ireland, and some Romani settlements in Slovenia). In the United States, roughly 18 million Americans live in one of 50,000 trailer parks (Berlin 2011), meaning that more than $6 \%$ of all occupied housing units are mobile homes or trailers (U.S. Department of Housing and Urban Development / U.S. Census Bureau 2013, 8). While there are doubtlessly some people who live in a mobile home through choice, as the number of people living in poverty rises (according to the National Poverty Center (n.d.), 15.1\% of U.S. Americans were poor in 2010, the highest rate since 1993), the booming trailer-park economy reflects the ever greater income gap.

A comparison of the term 'mobile home', in American and British corpora is more than telling: while a search in COCA retrieves 601 instances of 'mobile home', the BNC contains only 50 instances of 'mobile home'. Taking into account the disparity in the sizes of the corpora, the difference is statistically significant. Similar evidence is shown by comparing 'trailer park' and 'caravan park', 'caravan' being the usual British term where Americans use 'trailer'; the combination with 'park' is used to confine the investigation only to cases of trailers/caravans as accommodation. The COCA corpus has 418 instances of 'trailer park' and 0 instances of 'caravan park', while the BNC returns 3 hits for 'trailer park' and 55 for 'caravan park'; again the results are statistically significant.

It is difficult to compare the proportion of poor people. The CIA Factbook gives the percentage of population living below the poverty line as 15.1 for the USA, 16.2 for Britain, and 13.5 for Slovenia, but these numbers refer to nationally determined poverty rates and the thresholds differ across countries. The proportion of population living below the absolute poverty rate of 2 dollars per day is $0.0 \%$ in all three countries, showing that people's basic needs are in principle catered for. What can be compared, however, is the Gini coefficient, ${ }^{15}$ and the distribution of income is the least unequal (0.237) in Slovenia, with the United Kingdom (0.323) and the United States (0.45) having considerably more inequality (CIA, n.d., estimates for 2007-2012).

The fact that Slovenia has the lowest levels of inequality among the three nations compared is a direct consequence of its socialist past and Slovenian homes likewise still bear this past's imprint. Throughout the fifty years of planned economy, the limited selection of furniture and furnishings available on the market resulted in a fairly uniform look of the interior of people's homes - today Ikea seems to be the great equalizer. If it can be assumed that citizens' satisfaction is determined

15 A measure of income inequality, the Gini coefficient ranges from 0 (income distributed completely equally) to 1 (all income goes to one person) ("Gini Coefficient" 2007). 
not only by what they have or do not have, but also by what others have that they do not have, it becomes easier to understand why, despite the smaller average size of housing units and number of rooms per person, 93\% of Slovenians claim a high satisfaction with their current housing situation compared to $89 \%$ of Britons and $86 \%$ of U.S. Americans (OECD, n.d.).

\subsection{Home Sweet Home}

The basic definitions of 'house', "a building for habitation", and 'home', which is first and foremost "the place where a person or animal dwells" and only secondly "[t]he place where one lives or was brought up, with reference to the feelings of belonging, comfort, etc., associated with it" (Oxford English Dictionary 2015), are so close that there are many cases where the two expressions are interchangeable, for instance, 'moving house' or 'moving home'. To the Slovenian mind, both expressions are surprising, partly because of their grammar (where 'moving a house/home' might mean transferring the actual structure to a new location, and 'moving home' may also express the direction, for instance, 'moving back home') but in part - especially talking about moving home because the notions of house and home are much more closely connected and tied to the physical in the Slovenian culture. In the Slovenian context, one cannot actually separate the home from the house and can consequently not move home; because the two are inseparable, the only thing they can do is create a new home in a different house. Tellingly, the Slovenian expression can only be seliti se (move) with the optional addition of $v$ novo hiso/v nov dom (into a new house/a new home), never seliti hišoldom (move house/home).

No doubt the difference in the perception of the two notions is related to the considerable differences in ownership rates that can be observed: $90 \%$ of all Slovenian households are owneroccupied, compared to 65\% in the United Kingdom and 64\% in the USA (Dolenc et al. 2013, 42; Department for Communities and Local Government 2014, 8; Callis and Kresin 2014). It is easy to hypothesize that owning a home enables greater attachment. On the other hand, it is also conceivable that the conditioning might work the other way around as well so that residents would go to greater lengths to acquire a home. ${ }^{16}$

This affective factor does not only apply to tenants wanting to buy the home they live in but also to building one's house from scratch: it is still the 'Slovenian Dream' to commission the building of one's house and to have its layout tailored to whatever wishes the future owner might express. Such methods are quite rare in English-speaking cultures, where houses will typically be developed by private companies or in some cases local authorities (the former has lately become quite common also in Slovenia). This peculiarity also helps explain why Slovenian homes have so far been less uniform in appearance.

In the past the building of a house in Slovenia was not only commissioned but also executed by the owner (with the help of family and friends - as recently as the 1980s this was an important form of constructing detached houses; see Malešič in Vrečko 2014). As a consequence, there is also the attachment to the 'fruit of one's labour', or perhaps respect for the work of the owner's parents. In contrast, two thirds of all inherited British homes are sold immediately by the new owners (O’Driscoll 2004, 177). ${ }^{17}$

\footnotetext{
16 Cf. the film Slovenka (Slovenian Girl, 2009) about a university student who prostitutes herself for the express purpose of buying and holding onto an expensive unfurnished flat - something that might be particularly difficult for non-Slovenian audiences to comprehend.

17 Cf. also Jason Blake's $(2011,97)$ observation that it is much more expensive to buy property in Slovenia than it is to rent it, "because Slovenians consider it a waste of money to pay for something you do not own."
} 
The underlying reason for how much attachment there is to the house where one dwells seems to be linked to how prevalent mobility is in the society. As a country of just over 20,000 square kilometres (less than 8,000 square miles), Slovenia normally enables its citizens to live and work in the same area. There is relatively little in-country mobility and emigration figures are also traditionally low - apparently, it is just not a country of movers. ${ }^{18}$ Size does matter, it seems, and it can be claimed that it is partly the sheer vastness of the USA that both facilitates and necessitates inter-state migration. Together with other contributing factors, such as cheaper and less regulated housing, the immigrant character of the nation, or job market flexibility, this helps to explain why internal mobility is still ${ }^{19}$ significantly higher in the USA compared to European countries (Molloy, Smith, and Wozniak 2011).

While the concepts involved are fairly abstract, a corpus analysis can nevertheless be attempted. Using the collocation functions available in the three corpora used, the first twenty collocates (limited to the first position on the left) yielded for 'house' ( $\left.h i s^{2} a\right)$ and 'home' $(d o m)^{20}$ are given in tables 1 and 2 , respectively. ${ }^{21}$

Analysis of the data shows that some of the collocations are roughly equivalent, especially when it comes to prepositions or cases where 'house' is understood to mean an organization, for instance, 'safe house', 'opera house', 'publishing house' (also, for instance, 'fashion house', even though only the Slovenian expression ranks so highly among collocates). A close look suggests three kinds of differences.

The first type has to do with simple linguistic differences - for example, the expression for a 'guest house' in Slovenian includes neither a house nor a home but the notion is expressed by a separate lexeme, gostišce (or penzion). The same is true of cases such as a 'manor house' or 'country house' (grašcina) and a 'public house' (gostilna), and likewise of the Slovenian borzna or borznoposredniška hiša, which can be rendered in English as one word, 'brokerage'.

Yet other cases involve the uses of a multi-word lexeme that does not include 'house' or 'home', for instance, klirinška družba (society) for 'clearing house', polna dvorana (hall) for 'full house', ${ }^{22}$ or pogrebni zavod (institution) for 'funeral home', and conversely 'car park' for garažnalparkirna hiša, 'birth place' for rojstna hiša, and 'media company' and 'production company' for medijska hiša and produkcijska hiša. The cases of 'public house' and mestna hiša are particularly interesting because their literal translations are in fact collocations in the other language as well but mean something

18 There have been exceptions due to economic and political reasons, and the latest economic crisis has likewise seen the number of emigrants rise but the overall level of emigration is still relatively low and with the exception of one year (2010), Slovenia remains a net immigration country (Eurostat, n.d.). Nevertheless, these attitudes may well be changing as the younger generations seem more open to both moving abroad and commuting within the country.

19 Alexis de Tocqueville ([1835/1840] 1994, 136) is known for his remark that " $\mathrm{i}] \mathrm{n}$ the United States a man builds a house in which to spend his old age, and he sells it before the roof is on $[\ldots]$ " Teague's $(2011,79)$ data suggest not much has changed: "In an average one-year period, one in five Americans relocates - 25 percent move to an entirely new state or region."

20 It is important to note that the English and Slovenian terms are not introduced here as equivalents but as concepts belonging to the same semantic field. This means that they belong to "a set of lexemes which cover a certain conceptual domain and which bear certain specifiable relations to one another" (Lehrer and Battan 1983, 119) - but the exact "specifiable relations" which they "bear to one another" within and across languages are yet to be determined.

21 All statistics use lemmas, where applicable. The results for the BNC and Gigafida corpora are based on log-likelihood as a measure of collocational strength to give preference to commonly used expressions (see Arhar and Gorjanc 2007, 105). The results for the COCA corpus are based on raw frequencies because the only other option available is the ranking based on mutual information, which proves less than informative (for instance, the top three collocates of 'house' are the hashtag ('\#'), '435-member' and 'AikenRhett'); all collocate queries in COCA apparently automatically exclude the definite and indefinite articles.

22 While this is true of many of these collocations (at least to some extent), a full house in particular can mean a number of things besides referring to how busy a place is, it is also often used as a political term, or as a hand in poker. 
TABle 1. Collocates of 'house' (hiša) in BNC, COCA and Gigafida (1L).

\begin{tabular}{|c|c|c|c|}
\hline $\begin{array}{l}\text { Order of } \\
\text { collocates }\end{array}$ & BNC & COCA & Gigafida \\
\hline 1 & the & white & stanovanjski (residential) \\
\hline 2 & white & 's & bel (white) \\
\hline 3 & 's & my & garažen (garage, adj.) \\
\hline 4 & opera & your & mesten (town/city, adj.) \\
\hline 5 & manor & our & $v$ (in) \\
\hline 6 & a & random & časopisen (newspaper, adj.) \\
\hline 7 & this & old & medijski (media, adj.) \\
\hline 8 & your & opera & rojsten (birth, adj.) \\
\hline 9 & guest & town & varen (safe) \\
\hline 10 & his & beach & biti (be) \\
\hline 11 & my & ranch & Riko \\
\hline 12 & clearing & full & star (old) \\
\hline 13 & country & main & parkiren (parking, adj.) \\
\hline 14 & upper & safe & založniški (publishing, adj.) \\
\hline 15 & council & guest & operen (opera, adj.) \\
\hline 16 & our & halfway & borzen (stock exchange, adj.) \\
\hline 17 & terraced & publishing & borznoposredniški (brokerage, adj.) \\
\hline 18 & lower & clean & večstanovanjski (multi-unit, adj.) \\
\hline 19 & big & brick & moden (fashion, adj.) \\
\hline 20 & public & empty & produkcijski (production, adj.) \\
\hline
\end{tabular}


Table 2. Collocates of 'home' (dom) in BNC, COCA and Gigafida (1L).

\begin{tabular}{|c|c|c|c|}
\hline $\begin{array}{l}\text { Order of } \\
\text { collocates }\end{array}$ & BNC & COCA & Gigafida \\
\hline 1 & at & at & Cankarjev \\
\hline 2 & go & come & zdravstven (health, adj.) \\
\hline 3 & come & go & kulturen (cultural) \\
\hline 4 & his & back & gasilski (fire brigade, adj.) \\
\hline 5 & nursing & get & naroden (national/people's, adj.) \\
\hline 6 & back & your & $\begin{array}{l}\text { dijaški (secondary school } \\
\text { student, adj.) }\end{array}$ \\
\hline 7 & the & return & študentski (university student, adj.) \\
\hline 8 & came & nursing & na (on) \\
\hline 9 & their & stay & svoj (one's) \\
\hline 10 & your & way & biti (be) \\
\hline 11 & coming & bring & predstavniški (representative) \\
\hline 12 & her & leave & delavski (workers', adj.) \\
\hline 13 & returned & drive & planinski (mountain, adj.) \\
\hline 14 & went & own & zadružen (cooperative, adj.) \\
\hline 15 & way & funeral & azilen (asylum, adj.) \\
\hline 16 & going & walk & $v$ (in) \\
\hline 17 & return & send & materinski (maternal) \\
\hline 18 & matrimonial & ride & počitniški (vacation, adj.) \\
\hline 19 & from & arrive & $o d$ (from) \\
\hline 20 & get & hit & celjski (Celje, adj.) \\
\hline
\end{tabular}


different: javna hiša 'public house' in Slovenian is a brothel, rather than a pub, and a 'town house' in English is a descriptive term rather than a town/city hall, which is what mestna hiša denotes.

Less arbitrary are the grammatical differences. It can be observed that many of the collocates in English belong to the group of determiners. While articles do not have a counterpart in Slovenian, possessives exist in that language as well but are conspicuously absent from the tables, with the exception of svoj (one's). Any interpretations leaning towards a greater importance of private property in the English-speaking world would be exaggerated: because the use of determiners is obligatory with singular countable nouns and this role can be fulfilled by possessives, they simply happen to be overall more common in English compared to Slovenian due to structural grammatical reasons (see also Pisanski Peterlin 2009).

The second type has to do with examples of easily observable differences in the real world such as described in this paper, where to understand and appreciate the collocation one needs to know about the characteristics of homes in the three cultures: 'terraced houses' are typical of the UK, and 'beach houses' and 'ranch houses' are conditioned by American geography and urban planning. The presence of 'big house' and 'main house' recalls the previous discussion of the size of dwellings. Also present are expressions that have to do with specific practices in individual countries: 'council houses' in the UK are a type of social housing built by local councils, and a 'halfway house' is a part of the American correctional system that serves to facilitate the reintegration of ex-convicts. On the other hand, it is very common in Slovenia ${ }^{23}$ for two or more families (as a rule belonging to the same extended family) to live in the same house (see Šabec and Limon 2001, 104), hence - at least partly - the significance of the terms stanovanjska hiša ${ }^{24}$ and večstanovanjska hiša (residential house; multi-unit house) in Slovenian.

Some names of institutions widely present in the society (or at least in the textual samples included in the corpus) are also listed: Random House (publishing house), Riko hiše (construction company), Cankarjev dom (cultural and congress centre), Narodni dom (name of several cultural centres), Delavski dom (cultural centre), Celjski dom (cultural centre). ${ }^{25}$ Similarly, the high prominence of the White House in the American society but also in the world media accounts for the greater part of occurrences of 'white house' in all three corpora.

Finally, the different attitude towards house compared to home discussed above can help explain a number of differences in the usage of the two words. Easily discernible is the fact that a chamber in a political sense is also referred to as a 'house' in English (so that the British Parliament is divided into the Upper House and the Lower House) but a dom (home) in Slovenian (interestingly, the concordances for predstavniski dom (representative home) in the Slovenian corpus refer almost exclusively to the U.S. House of Representatives).

This disparity is no coincidence. What can be observed and has been discussed previously in this section is the fact that the relationship between 'house' and 'home' is much closer in Slovenian than in English, and the idea of a home is almost impossible to separate from its physical representation in the form of an actual building. As a consequence, the semantic scope of dom (home) can cover much of what is subsumed by 'house' alone in English and can furthermore include buildings for

23 Apparently, this trend is gaining ground in the USA as well, with multi-family housing accounting for $40 \%$ of all newly constructed homes in 2013 (Frizell 2014).

24 To a large extent, the use of the adjective stanovanjska (residential) appears pleonastic, as houses are expected to be places of residence, and is characteristic of legal and business discourse.

25 Several of these institutions in Slovenia go back to the days of the Austro-Hungarian Empire and later socialism, and the idea of the community taking care of the cultural edification of individuals. 
various activities, such as zdravstveni, kulturni and zadružni dom (health, cultural, community centre), gasilski dom (fire station), dijaški and študentski dom (student residence), azilni dom (asylum accommodation centre), as well as planinski and počitniški dom (types of holiday accommodation, the first one found specifically in the mountains).

Another example, materinski dom, can be rendered as a '(mother and baby) home' in English as well, because it comprises both dimensions of home described: the physical rapport with a building in Slovenian, and the abstract concept of an intimate place where one feels sheltered and comfortable in English (cf. also 'nursing home', in Slovenian dom upokojencev or 'home of retired people'). It is this latter dimension that is very much present in the collocates for 'home' found in British and American English, both with adjectives such as 'matrimonial' and in activities having to do with this private sphere, for instance, 'come/return/leave/arrive home'.

\section{Conclusion}

Examining a field as run-of-the-mill as house and home confirms how misguided it is to think of cultures as compilations of various unrelated practices, or to say how quaint the British/Americans/ Slovenians are (or indeed any 'tribe'), because they do this or that: a culture is not a cabinet of curiosities where one can be fascinated by a particular artefact without any regard for the rest. Instead, what the analysis presented shows is that even seemingly banal details will often (but not necessarily always) be tied to other concepts and the system of values in the culture. It is equally evident that to really understand a language and appreciate its nuances, one must pay attention to the culture(s) where it is spoken, even in times of globalization and English as a lingua franca, because many linguistic phenomena, such as frequently used word combinations, do not exist in a void but are the direct result of cultural practices.

The subject tackled is broad in scope and all of the topics explored would benefit from further and more detailed analyses, possibly extending the research to other (English- and non-Englishspeaking) environments. Despite these limitations and despite the fact that it can be difficult to investigate the rationale behind cultural practices and abstract concepts cross-culturally with the necessary academic rigour, the paper brings together a number of ideas from different fields to provide insights into how people approach and talk about house and home, and how their manner of doing so is related to some of the central tenets of the cultures they are surrounded by. The notions discussed are corroborated with quantitative and qualitative data wherever possible. In this way, the paper contributes a new piece of evidence to show that the link between language and culture is of utmost importance, and that one's home may only be a castle in one's specific culture - and quite possibly seen as something else altogether in another.

\section{References}

Amebis. n.d. "O korpusu.” Accessed January 29, 2015. http://www.gigafida.net/Support/About.

American Forest and Paper Association. 2001. Details for Conventional Wood Frame Construction. Accessed January 29, 2015. http://www.awc.org/pdf/wcd1-300.pdf.

Arhar, Špela, and Vojko Gorjanc. 2007. "Korpus Fidaplus: nova generacija slovenskega referenčnega korpusa." Jezik in slovstvo 52 (2): 95-110.

"Bauhaus." 2013. In The Columbia Encyclopedia. New York: Columbia University Press. Accessed January 29, 2015. http://search.credoreference.com/content/entry/columency/bauhaus/0. 
Berlin, Loren. 2011. "At More Mobile-Home Parks, a Greater Sense of Security.” New York Times, March 16. Accessed January 29, 2015. http://www.nytimes.com/2011/03/17/garden/17trailer.html?_r=0.

Blake, Jason. 2011. Culture Smart! Slovenia. London: Kuperard.

BNCweb (CQP edition). 1996-2013. Accessed January 29, 2015. http://bncweb.lancs.ac.uk/.

Brinkley, Mark. 2009. “The Evolution of Timber Frame.” Homebuilding \& Renovating, August. Accessed January 29, 2015. http://www.homebuilding.co.uk/advice/key-choices/structural/evolution-timber-frame.

Brown, Michael F. 2008. "Cultural Relativism 2.0.” Current Anthropology 49 (3): 363-83.

Budak, Jelena, Ivan-Damir Anić, and Edo Rajh. 2013. "Public Attitudes towards Privacy and Surveillance in Croatia." Innovation: The European Journal of Social Science Research 26 (1-2): 100-18. doi:10.1080/135116 10.2013 .723404 .

Burnard, Lou, ed. 2007. "Reference Guide for the British National Corpus (XML Edition).” Accessed January 29, 2015. http://www.natcorp.ox.ac.uk/docs/URG/.

Byram, Michael, Carol Morgan et al. 1994. Teaching-and-Learning Language-and-Culture. Clevedon: Multilingual Matters.

Callis, Robert R., and Melissa Kresin. 2014. Residential Vacancies and Homeownership in the Third Quarter 2014. Accessed January 29, 2015. http://www.census.gov/housing/hvs/files/qtr314/q314press.pdf.

CIA. n.d. "The World Factbook." Accessed January 29, 2015. https:/www.cia.gov/library/publications/theworld-factbook/geos/us.html.

COCA. Corpus of Contemporary American English. n.d. Accessed January 29, 2015. http://corpus.byu.edu/cocal.

Council of Europe. 1950. European Convention for the Protection of Human Rights and Fundamental Freedoms, as Amended by Protocols Nos. 11 and 14. Accessed January 29, 2015. http://www.echr.coe.int/Documents/ Convention ENG.pdf.

Council of Študentski Dom Ljubljana. 2014. Dormitory Rules of Študentski Dom [Student Residences] Ljubljana. Accessed January 29, 2015. http://www.stud-dom-lj.si/sites/www.stud-dom-lj.si/files/domski_red_sdl_ang_cistopis julij in oktober 2014 0.pdf.

de Tocqueville, Alexis. (1835/1840) 1994. Democracy in America. London: David Campbell.

Deane, Neil. 2014. Modern Germany - An Outsider's View from the Inside. Berlin: Pro Business.

Department for Communities and Local Government. 2010. English Housing Survey: Housing Stock Report 2008. Accessed January 29, 2015. https:/www.gov.uk/government/uploads/system/uploads/attachment data/ file/6703/1750754.pdf.

-. 2014. English Housing Survey: Households. Annual Report on England's Households, 2012-2013. Accessed January 29, 2015. https://www.gov.uk/government/uploads/system/uploads/attachment data/file/335751/ EHS Households Report 2012-13.pdf.

Dolenc, Danilo, Erna Miklič, Barica Razpotnik, Darja Šter, and Tina Žnidaršič. 2013. Ljudje, družine, stanovanja: Registrski popis 2011. Ljubljana: Statistični urad Republike Slovenije. Accessed January 29, 2015. www.stat.si/doc/pub/Ljudje druzine stanovanja.pdf.

Dunton, Jim. 2014. “Uni Fire Rekindles Debate on Timber Framed Buildings.” The Architects' Journal, September 17. Accessed January 29, 2015. http://www.architectsjournal.co.uk/news/uni-fire-rekindlesdebate-on-timber-framed-buildings/8669730.article.

Equality and Human Rights Commission. 2012. Human Rights Review 2012. How Fair Is Britain? An Assessment of How Well Public Authorities Protect Human Rights. Accessed January 29, 2015. http://www. equalityhumanrights.com/sites/default/files/documents/humanrights/ehrc_hrr_full_v1.pdf. 
Eurostat. n.d. “Crude Rate of Net Migration plus Adjustment.” Accessed April 24, 2015. http://ec.europa.eu/ eurostat $/ \mathrm{tgm} /$ table.do?tab=table\&init=1 \&language=en\&pcode=tsdde230\&plugin=1.

Fenner, Anne-Brit. 2001. "Introduction." In Cultural Awareness and Language Awareness Based on Dialogic Interaction with Texts in Foreign Language Learning, edited by Anne-Brit Fenner, 5-11. Graz: European Centre for Modern Languages / Council of Europe Publishing.

Ford, Martyn, and Peter Legon. 2003. The How to Be British Collection. London: Lee Gone Publications.

Fox, Kate. 2004. Watching the English: The Hidden Rules of English Behaviour. London: Hodder.

Frizell, Sam. 2014. "The New American Dream Is Living in a City, Not Owning a House in the Suburbs." Time, April 25. Accessed April 24, 2015. http://time.com/72281/american-housing.

Gigafida. Korpus slovenskega jezika. n.d. Accessed January 29, 2015. http://www.gigafida.net.

“Gini Coefficient.” 2007. In Poverty: An International Glossary. London: Zed Books. Accessed January 29, 2015. http://search.credoreference.com/content/entry/zedpoverty/gini coefficient/0.

Hager, Michael. 2011. Culture, Psychology, and Language Learning. Oxford: Peter Lang.

Holliday, Adrian, Martin Hyde, and John Kullman. (2004) 2006. Intercultural Communication: An Advanced Resource Book. London: Routledge.

"Intervju: Zdi se mi potratno, da bi si zgradil hišo iz opeke in betona." 2014. Finance. Oglasna priloga, May 4. Accessed January 29, 2015. http://www.finance.si/8801651/Intervju-Zdi-se-mi-potratno-da-bi-si-zgradilhi\%C5\%A1o-iz-opeke-in-betona?\&cookie dialog=1\&cookietime=1421510185.

Kitek Kuzman, Manja, Jože Kušar, and Jasna Hrovatin. 2007. "Smernice in potencial lesene gradnje v Sloveniji." Arhitektura, raziskave 2007 (1): 33-38.

Kitek Kuzman, Manja, and Srečko Vratuša. 2011. "Energijsko varčna lesena gradnja v Sloveniji.” Arhitektura, raziskave 2011 (1): 29-34.

Kramsch, Claire. (1998) 2014. Language and Culture. Oxford: Oxford University Press.

Lehrer, Adrienne, and Paul Lanan Battan. 1983. "Semantic Fields and Semantic Change." Coyote Papers: Working Papers in Linguistics 4. Exploring Language: Linguistic Heresies from the Desert, edited by Esmerelda MartinCallejo-Manandise, 119-28. Tucson: University of Arizona. Accessed April 24, 2015. https://arizona. openrepository.com/arizona/bitstream/10150/226537/1/cpiv-119-128.pdf.

Martin, Gary. 1996-2015. “The Meaning and Origin of the Expression: Daylight Robbery.” Accessed January 29, 2015. http://www.phrases.org.uk/meanings/daylight\%20robbery.html.

Molloy, Raven, Christopher L. Smith, and Abigail Wozniak. 2011. “Internal Migration in United States.” Journal of Economic Perspectives 25 (3): 173-96. doi:10.1257/jep.25.3.173.

National Poverty Center. n.d. “Poverty in the United States: Frequently Asked Questions.” Accessed January 29, 2015. http://www.npc.umich.edu/poverty.

O’Driscoll, James. 2004. Britain. Oxford: Oxford University Press.

OECD. n.d. "Better Life Index: Housing." Accessed January 29, 2015. http://www.oecdbetterlifeindex.org/ topics/housing.

Oxford English Dictionary. 2015. Oxford University Press. Accessed January 29, 2015. http://www.oed.com/.

Pisanski Peterlin, Agnes. 2009. "Izražanje svojilnosti v prevedeni slovenščini: korpusna analiza.” In Jezikovni korpusi v medkulturni komunikaciji, edited by Vesna Mikolič, 105-16. Koper: Univerza na Primorskem / Znanstveno-raziskovalno središče / Založba Annales / Zgodovinsko društvo za južno Primorsko.

Richmond, Yale. 2009. Understanding the Americans. A Handbook for Visitors to the United States. New York: Hippocrene Books. 
Rosch, Eleanor. 1978. "Principles of Categorization." In Cognition and Categorization, edited by Eleanor Rosch and Barbara B. Lloyd, 27-48. Hillsdale: Lawrence Erlbaum. Accessed January 29, 2015. http:// commonweb.unifr.ch/artsdean/pub/gestens/f/as/files/4610/9778 083247.pdf.

Schmich, Mary. 2011. "How Many Bathrooms Do You need? To Many Americans, the More at Home, the Better." Chicago Tribune, July 1. Accessed January 29, 2015. http://articles.chicagotribune.com/2011-07-01/ news/ct-met-schmich-0701-20110701 1 bathroom-chicago-houses-fran-bailey.

Senft, Gunter, Jan-Ola Östman, and Jef Verschueren, eds. 2009. Culture and Language Use. Amsterdam: John Benjamins.

Slovenka. 2009. Directed by Damjan Kozole. Vertigo/Emotionfilm.

Son, Jeong-Bae, and Ann Dashwood, eds. 2011. Language, Culture and Social Connectedness. Newcastle upon Tyne: Cambridge Scholars.

Spencer-Oatey, Helen, ed. 2008. Culturally Speaking. Culture, Communication and Politeness Theory, 2nd ed. London: Continuum.

Structural Timber Association. 2014-2015. Accessed January 29, 2015. http://www.structuraltimber.co.uk/.

Šabec, Nada, and David Limon. 2001. Across Cultures. Slovensko-britansko-ameriško sporazumevanje/SloveneBritish-American Intercultural Communication. Maribor: Založba Obzorja.

Teague, Gina. 2011. Culture Smart! USA. London: Kuperard. First published 2006.

The SelfBuild Guide. 2009-2013. “Why Choose Masonry Construction?” Accessed January 29, 2015. http:// www.the-self-build-guide.co.uk/masonry-construction.html.

Trosborg, Anna, ed. 2010. Pragmatics across Languages and Cultures. Berlin: De Gruyter Mouton.

UK Timber Frame Association [Structural Timber Association]. 2010. Market Report 2009. Accessed January 29, 2015. http://www.forestryscotland.com/media/38870/2010 timbertrends report final[1].pdf.

U.S. Census Bureau, Housing and Household Economic Statistics Division. 2011. Historical Census of Housing Tables: Units in Structure. Accessed January 29, 2015. https:/www.census.gov/hhes/www/housing/census/ historic/units.html.

U.S. Department of Housing and Urban Development / U.S. Census Bureau. 2013. American Housing Survey for the United States: 2011. Accessed January 29, 2015. http://www.census.gov/content/dam/Census/programssurveys/ahs/data/2011/h150-11.pdf.

Vrečko, Asta. 2014. “Slovenska stanovanjska gradnja v času socializma.” Radio Študent, February 19. Accessed April 24, 2015. http://radiostudent.si/dru\%C5\%BEba/delavsko-punkerska-univerza/slovenskastanovanjska-gradnja-v-\%C4\%8Dasu-socializma.

WGBH Educational Foundation. 2000-2001. "Building Big: Materials Lab.” Accessed January 29, 2015. http:// www.pbs.org/wgbh/buildingbig/lab/materials text.html.

"Window Tax." 2002. In Dictionary of British History. Aylesbury: Market House Books Ltd. Accessed January 29, 2015. http://search.credoreference.com/content/entry/mhbh/window tax/0. 